\title{
Trends in automotive emissions legislation: impact on LD engine development, fuels, lubricants, and test methods - a global view, with a focus on WLTP and RDE regulations - Summary of the 6th International Exhaust Emissions Symposium (IEES)
}

\begin{abstract}
Among the drivers influencing vehicular powertrain development, the field of vehicular exhaust emissions is experiencing wideranging and rapid changes. New emissions regulations such as Euro 6d and new test methods (RDE and WLTP) are the main challenges for the automotive industry caused by political, socioeconomic and technical factors. Air quality is very high on the political agenda and pressure remains to limit and reduce greenhouse gas emissions from the road transport sector. In addition to limits becoming increasingly stringent, the list of parameters subject to legal limits are slowly expanding - and, most importantly, these limits must be met under a wide range of conditions. A range of strategies are available to overcome these difficulties, which was explored during the 6th International Exhaust Emissions Symposium (IEES) hosted at BOSMAL in June 2018. This paper reports and summarises the topics of the 6th IEES and attempts a synthesis on the current status of the field of IC engines, hybrid powertrains and electric vehicles and what the coming years may hold for the automotive and fuel industries and other allied fields.
\end{abstract}

Key words: global trends of exhaust emissions, emissions standard, IC engines, RDE, WLTP, WLTC, test methods, fuel development, hybrid and electric vehicles

\section{Introduction}

The most important factor affecting the development of drive systems in motor vehicles is currently the emission of harmful exhaust compounds from motor vehicles and the ways in which these emissions can be reduced.

The second most important factor is in reducing greenhouse gas emissions, particularly $\mathrm{CO}_{2}$ emitted by motor vehicles, which is also a political priority due to $\mathrm{CO}_{2}$ 's impact on global warming. In recent years, at the UNECE forum, within the GRPE group, work on the harmonisation of regulations of motor vehicles, the informal working groups (IWG): WLTP, PMP, EVE and others, as well as in the European Commission (WLTP 2nd act, RDE) have been working on the new WLTP emission test methodology - a new global harmonised laboratory test method and RDE - a method of testing emissions in road conditions using portable PEMS analysers.

Emission limits of particulate matter and nitrogen oxides have also tightened, and are being treated as a form of pollution with a significant negative impact on the environment [1].

The issue of harmful emissions, especially:

a) Nitrogen oxides - $\mathrm{NO}_{\mathrm{x}}$ from vehicles powered by compression ignition engines $(\mathrm{CI})$, which for vehicles meeting Euro 3, Euro 4, Euro 5 and Euro 6b standards, proved to be significantly greater in actual conditions of road use than in homologation laboratory measurements,

b) Particulate matter (whether quantified by mass - PM, or number - PN) in exhaust gases, not only from vehicles with CI engines, where the introduction of DPF filters has practically resolved this problem, but also from vehicles with spark ignition engines (SI), especially ones equipped with direct gasoline injection into the combustion chamber (GDI) that produce large amounts of parti- cles of very small diameters, so-called nanoparticles, which are very harmful to living organisms,

c) Non-exhaust particulate emissions, originating from other components such as brakes and tires, as well as volatile compounds emitted from the materials in new vehicles (Vehicle Internal Air Quality)

d) Carbon dioxide $\left(\mathrm{CO}_{2}\right)$, and fuel consumption (which is also related to global demand for fuel, energy security and plans for a decarbonised economy [2]) occurring in real world driving conditions,

are becoming a priority for the automotive sector, especially within the largest markets of the European Union, Japan, China, India and other Asian countries, South Korea, Brazil and the United States [3]. The development of engines and powertrains, and especially the possibilities of electronic control, have far outstripped the development of approval regulations in Europe, which has led to differences in emission measurements.

The response from the official legislative institutions dealing with this subject was the introduction of many legal acts specifying maximum levels of permissible exhaust emissions and test methodologies to quantify those emissions. Some pieces of legislation have imposed increasingly stringent emissions limits for individual harmful compounds; other have imposed series of mandatory guidelines for testing fuel consumption, as well as incentive plans for the introduction of low-carbon fuels and alternative fuels.

Now that it has become apparent that emissions of some compounds (especially $\mathrm{NO}_{\mathrm{x}}$, but also particulates and other pollutants, as well as $\mathrm{CO}_{2}$ ), measured in actual conditions can show a poor correlation with emissions results from laboratory tests. Measurement methods are subject to further change: this applies to both laboratory methods (e.g. new research procedures prepared by the EU/UN-ECE: WLTP/GTR15 [4], or US EPA: CFR 1065/1066); as well 
as emission and fuel consumption tests in real driving conditions (the test procedure prepared by the European Commission - RDE), which is so important that the RDE method has become an integral part of the procedure for testing emissions from motor vehicles. In September 2017 the EU introduced the requirements of WLTP and RDE to the new approval regulations referred to as Euro 6d-TEMP (as a transitional phase leading into Euro 6d), which completely changed the approach to the approval and certification of vehicles.

\section{Organisation of the symposium}

During the years 2010, 2011, 2012, 2014 and 2016, BOSMAL Automotive Research and Development Institute Ltd (hereafter BOSMAL), organised five International Symposia on vehicular exhaust emissions, covering issues related to limiting emission of harmful exhaust emissions from automotive sources and their impact on the development of vehicle powertrain design, the development of fuel technology, engine oils, exhaust gas treatment systems and new research methods [5], as this subject is vitally important for the further development of the motor industry globally, in Europe and of course in Poland. These symposia were very popular among professionals in the automotive and fuel industries, both foreign and domestic, who participated extensively in their deliberations.

On 14-15 June 2018, BOSMAL together with the Polish Scientific Society of Combustion Engines (PTNSS) was the organiser and at the same time hosted the next, being the sixth, international symposium on automotive exhaust emissions - The 6th International Exhaust Emissions Symposium entitled: "Trends in automotive emissions legislation: impact on LD engine development, fuels, lubricants and test methods - a global view, with a focus on WLTP and RDE regulations" (Fig. 1).

The programme for the symposium was organised and prepared by the International Organising Committee headed by Dr. Piotr Bielaczyc (BOSMAL/PTNSS), which also included well-known specialists from the USA, Switzerland, the UK, Germany and Italy.

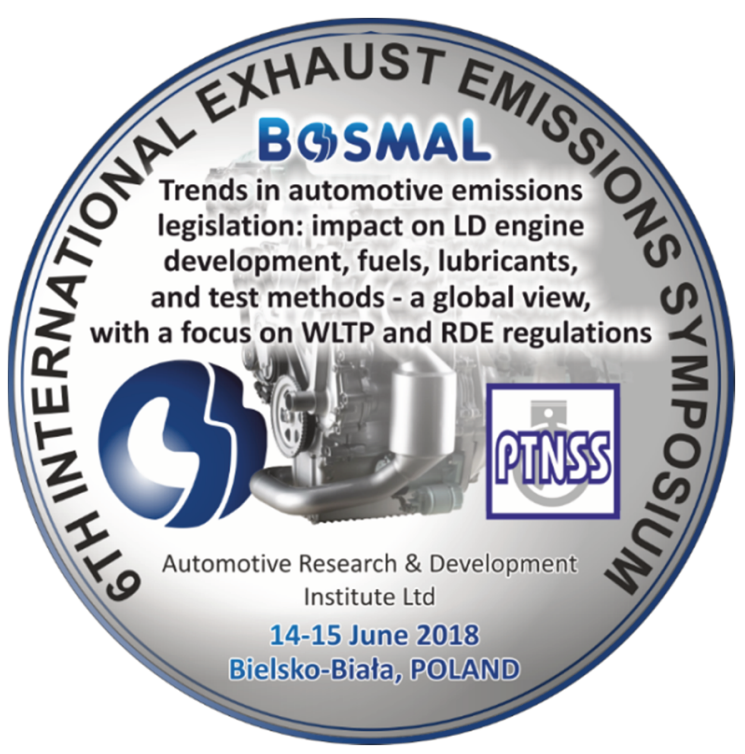

Fig. 1. Logo of the 6th Exhaust Emissions Symposium
It was the sixth time that leading experts from the USA and Europe met in Bielsko-Biala to discuss various aspects such as: the science of exhaust emissions and their control, socio-political aspects (i.e. pressure to limit real emissions from transport sources), legal and technical aspects (the impact of new global WLTP and RDE vehicle emission test methodologies), the development of powertrain design and optimisation, new "low-carbon" types of motor fuels, hybrid and electric powertrains, and trends in the development and testing processes for road vehicles, their powertrains, fuels and lubricants.

Discussions included the possibility of harmonising global regulations on emission reduction through the widespread introduction of the WLTP methodology requirements and also on the introduction of WLTP and RDE requirements for approval tests in the European Union from 1.09.2017, which significantly increased the mandate and powers of the authorities approving test facilities and certifying vehicles.

New (or improved) emission reduction methods, new solutions introduced to internal combustion engines and hybrid powertrains were discussed, as well as new emission test methodologies and the equipment needed for such tests. Advanced engine fuels/lubricants and alternative fuels' technical development were also topics discussed at length during the two-day event.

An important goal of this symposium was also the integration of the scientific and academic communities with the automotive industry (both in Poland and abroad), facilitating the establishment of new contacts, the exchange of knowledge on many issues, as well as promoting the achievements of Polish scientific and research institutions active in this field, especially BOSMAL.

This journal, the website DieselNet of Canada, the Polish journal Przegład Techniczny and the Polish Gazeo gaseous fuels internet portal provided the media patronage for the event.

More than 120 delegates participated representing 68 automotive and fuel industry companies, the European Commission (DG GROW from Brussels and the JRC Ispra Research Center), the US Government Research Center Argonne National Laboratory near Chicago, research institutes and industrial research centres from the automotive and fuel industries, and an international academic community from 17 countries (USA, UK, Spain, Greece, Italy, Switzerland, Austria, Luxembourg, Denmark, Belgium, Germany, the Netherlands, Sweden, Finland, France, Slovakia, the Czech Republic and Poland). The final programme (Fig. 2) contains details of all technical presentations and other information on the event.

Symposium guests were welcomed by BOSMAL Director Dr. Arkadiusz Stojecki (Fig. 3). The symposium was formally opened by Prof. Jerzy Merkisz (of PTNSS, Poznan University of Technology and BOSMAL), acting in his capacity of PTNSS president. Commencing the first technical session, the chairman of the International Organising Committee (BOSMAL's Dr. Piotr Bielaczyc) gave a preliminary presentation mentioning the symposium's main topics and setting the scene for the presentations and deliberations which followed. 


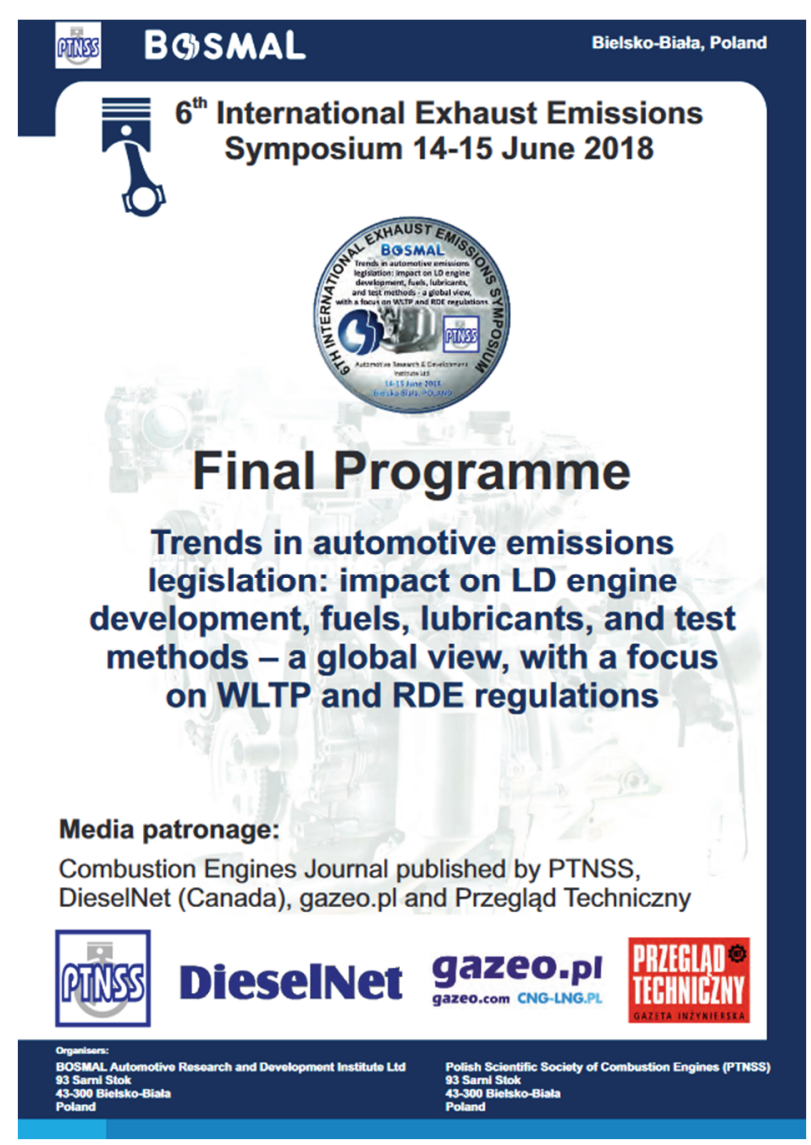

Fig. 2. First page of the Final Programme of the 6th Exhaust Emissions Symposium

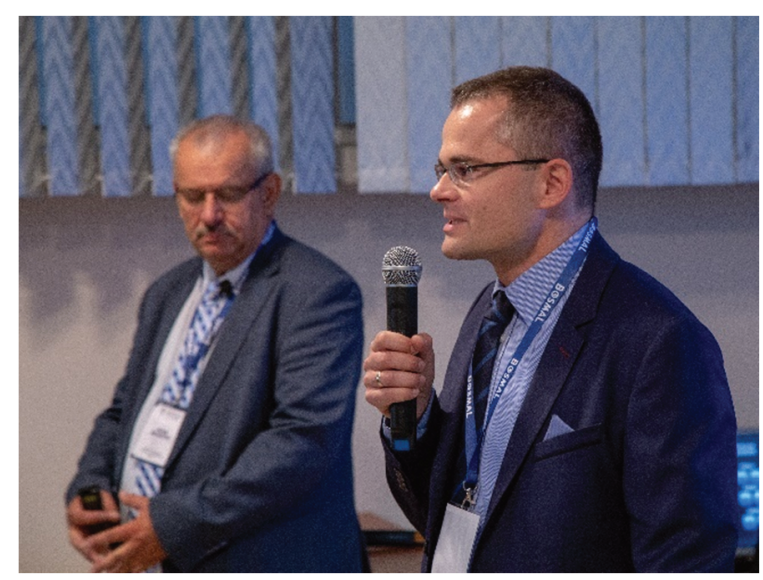

Fig. 3. BOSMAL director Dr. Arkadiusz Stojecki and Dr. Piotr Bielaczyc at the beginning of the event

\section{Global trends in reducing emissions from inter- nal combustion engines used in road transport}

Twenty five presentations were delivered during the symposium by well-known experts on emissions of harmful exhausts from motor vehicles, combustion engines, powertrain development (including hybrid and full electric), fuels and engine oils and development of research methods.

Furthermore, the invited American and European specialists presented nine technical posters.

Presentations were delivered during five plenary sessions covering various issues, with the following titles: a) "General automotive exhaust emissions",

b) $" \mathrm{CO}_{2}$, GHG \& Air Quality (including particulate matter)",

c) "Emissions reduction technologies \& aftertreatment",

d) "Test methods: laboratory based and RDE-PEMS",

e) "Fuel and Alternative powertrains".

\section{Symposium Sessions}

Individual sessions were chaired by well-known experts on car emissions: Wolfgang Thiel (Germany), Les Hill (UK), Amanda Lea-Langdon (UK) and Piotr Bielaczyc.

\subsubsection{First Session}

The first session was in relation to general aspects of vehicular emissions and global standards for their reduction.

The discussions during this first session included the new method for measuring emissions under real road driving conditions - RDE, as well as a newly-introduced chassis dynamometer WLTP procedure described in UNECE Regulation GTR 15, which has replaced the NEDC cycle in use since 2000 .

A comparison of emissions standards in the EU, USA, China, Japan, and India was presented. One of the presentations on this subject of the symposium was delivered by Dr. Piotr Bielaczyc (BOSMAL), who presented the most important technical, political and economic factors that currently affect the development of global road transport.

Global trends in reducing emissions from vehicles using the example of the European Union, Japan, USA, China and India were also discussed, as well as the main features of new EU emission standards - WLTP - developed by the GRPE (UNECE) and RDE groups, which were introduced into the EU approval requirements as the emission level Euro 6d-TEMP from $1^{\text {st }}$ September 2017, through Commission Regulations (EU) 2017/1151 and 2017/1154.

Dr. Bielaczyc's presentation also highlighted the impact of new emission testing methods on the development of automotive engine structures and future trends in vehicular powertrains. Despite the low esteem in which Diesel engines are held by many, manufacturers of these engines have already developed solutions based on SCR catalytic systems, which can ensure that this engine type has very low emissions of both PM/PN and $\mathrm{NO}_{\mathrm{x}}$.

A new trend in engine design is "rightsizing", as well as an ongoing convergence of spark ignition and compression ignition engine technology, with differences now much smaller than in the past (turbocharging, direct injection, compression ratio).

In the first session devoted to the regulations and methods of emission testing, further reports were presented by: Dr. Vicente Franco (European Commission, Belgium; Fig. 4) who presented the issues of air protection against pollution from automotive sources in the European Union (EU Clean air policy) and the latest data on the implementation of WLTP and RDE regulations in the European Union as tools to meet those aims.

Subsequent changes in research procedures will result in the fourth RDE package, which will also introduce tests of cars in use, to be performed by independent accredited 
laboratories as well as the vehicle manufacturers. The analysis of the next emission regulations, described as 'postEuro 6' - and even 'Euro 7' - has begun, which are to bring the same test methods and limits for all types of engines and fuels (a philosophy known as 'fuel-neutral' or 'technology-neutral', which already exists in the USA).

Les Hill (Horiba, UK; Fig. 5) presented trends in reducing emissions on a global scale as well as their impact on measurement procedures and the requirements for test equipment and methods. The US has introduced EPA Tier 3 and CARB LEV-III (in California) requirements, regulations on greenhouse gas emissions (GHG) and procedures defined in CFR Part 1065/1066 which are still being continually updated.

Japan plans to introduce testing methods based on the WLTP procedure (3-phase test without driving speeds $>100 \mathrm{~km} / \mathrm{h}$ ) and RDE tests for vehicles with CI engines. China and India likewise plan to introduce similar standards as in the EU, based on WLTP tests and methodology, and also RDE in the future. Thus, the precedent for RDE testing to expand from its point of origin in the EU to other legal jurisdictions over the next few years appears clear; particularly significant are the plans for introduction of rigorous $\mathrm{RDE}$ requirements by the large (and growing) markets of China and India. The formation of a new UN-ECE Informal Working Group for Global RDE reflects this situation.

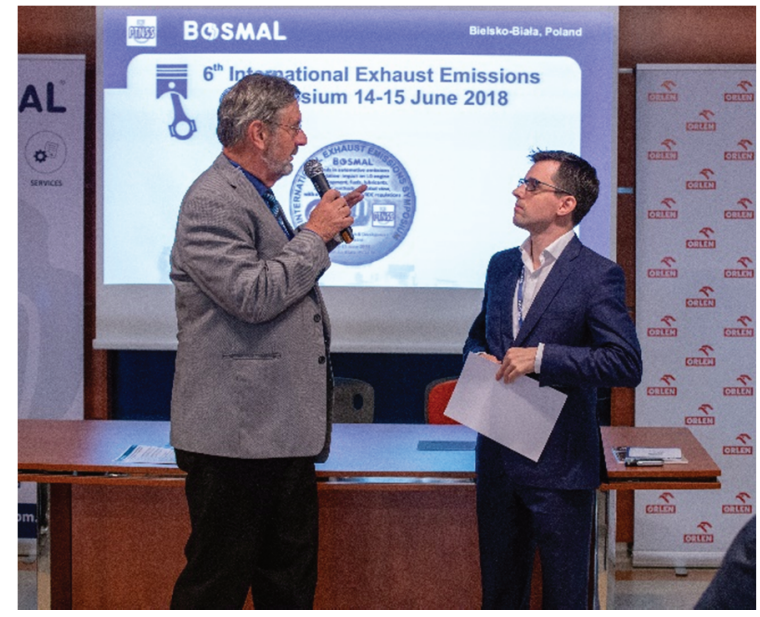

Fig. 4. Wolfgang Thiel (TRT Engineering, Germany) and Dr. Vicente Franco (European Commission, Belgium) during the first session

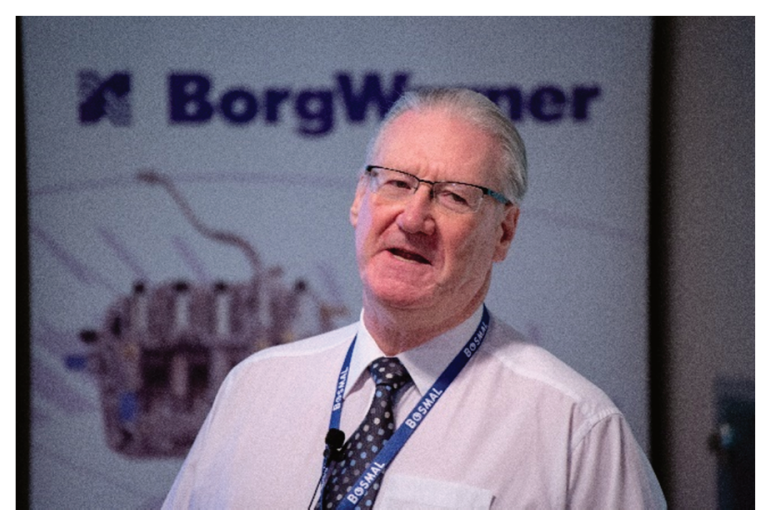

Fig. 5. Les Hill (Horiba, UK) delivering his presentation

\subsubsection{Second Session}

In the second session, covering greenhouse gas (GHG) emissions, $\mathrm{CO}_{2}$ emissions and particulates, Dr. Barouch Giechaskiel (JRC-Ispra, Italy; Fig. 6) presented two reports prepared by teams of specialists from the European Union's JRC Ispra research centre in Italy. He presented the problem of differences in the results of measurements of $\mathrm{CO}_{2}$ emissions in type approval tests using to the NEDC cycle and under real driving conditions, as well as the methods of compensating for these differences after the alteration of the test procedure via the WLTP.

This topic was also touched on by Prof. Luciano Rolando from Turin University of Technology who stated that $\mathrm{CO}_{2}$ emissions according to the WLTC cycle can be $10 \%$ to $24 \%$ higher using the WLTP procedure as opposed to the the NEDC, due to the higher energy demand in this cycle. The European Commission proposes to further reduce the average $\mathrm{CO}_{2}$ emissions of cars by $15 \%$ in 2025 and by $30 \%$ in 2030 in relation to the level from 2021 (though some parties continue to lobby for even higher reductions). Dr. Amanda Lea-Langdon from the University of Manchester in the UK presented the methodology and some results of advanced optical measurements of solid particles.

In his second contribution to the debate, Dr. Giechaskiel presented the work of the PMP group on measurements of $\mathrm{PM} / \mathrm{PN}$ emissions and on the extension of the testing methodology of the number of nanoparticles (PN) for the current cut-off point of $23 \mathrm{~nm}$ down to $10 \mathrm{~nm}$, to assess the emission of these particles which are currently not subject to limitation, which is significant especially in the case of gasoline and gaseous-fuelled engines. He also discussed the work of the PMP team on the introduction of methods testing and measuring the emission of particles generated from the brake discs and pads in cars and the planned work for new emission standards at the post-Euro 6 level.

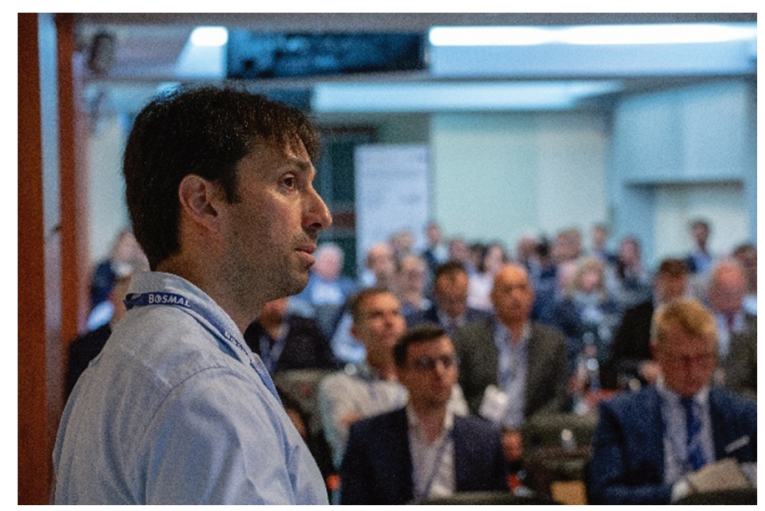

Fig. 6. Dr. Barouch Giechaskiel - (EC JRC-Ispra, Italy) delivering his presentation

\subsubsection{Third Session}

The third session, concerning emission reduction methods and catalytic exhaust gas aftertreatment systems, consisted of two parts and had the largest number of presentations. It was opened by Dr. Ameya Joshi (Corning, USA), who gave a speech about the methods for limiting engine emissions through catalytic systems, also for hybrid power- 
trains in which the TWC and other catalytic reactors may undergo cooling when the combustion engine is not running. He also talked about the possibilities of increasing the efficiency of car engines. $45 \%$ thermal efficiency has already been achieved for SI engines, but further development in this field is still possible - currently a level of 55\% for the $\mathrm{CI}$ engines used in HD applications are being worked on. A significant part of his report was devoted to catalytic aftertreatment (SCR, SCRF, PNA, methane oxidation catalysts) as well as multi-component systems of catalytic reactors and filters which can allow engines to meet legal emissions requirements under a wide range of operating conditions.

Kurt Engeljehringer (AVL, Austria; Fig. 7) spoke about the influence of RDE emissions standards on the development of research methods on both engine and chassis dynamometers. To meet the RDE standards, ECU adjustments must be performed on both engine dynos and verified on the chassis dyno in emission testing laboratories where $\mathrm{RDE}$ tests performed on the road are reproduced.

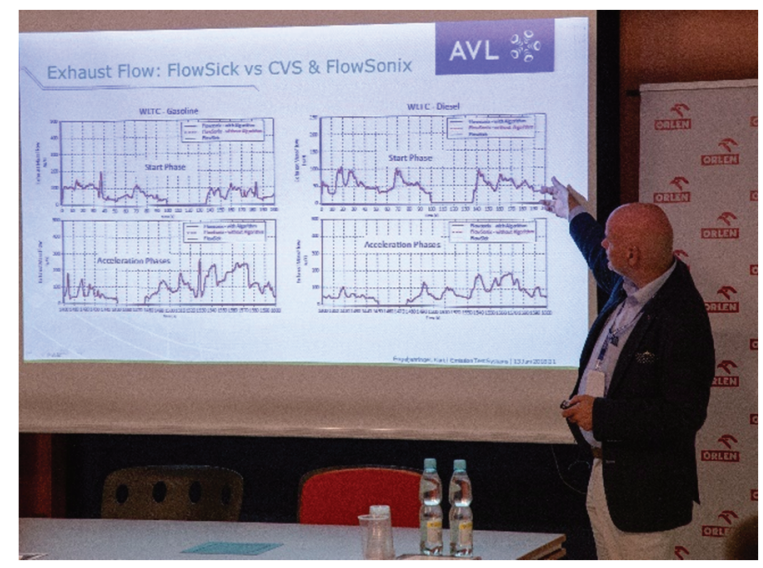

Fig. 7. Kurt Engeljehringer (AVL, Austria) delivering his presentation

An important element of the strategy of reducing emissions by internal combustion engines is advanced engine control systems in cars - made possible by ECUs, whose calibration methods were presented by Dr. Marcos Alonso Baez (Nissan Technology Center, Spain; Fig. 8). This method is based on ECU modelling in terms of RDE emission requirements and is referred to as MBC (model based calibration). It allows optimising of the ECU function that controls the operation of the engine and its systems in terms of low $\mathrm{NO}_{\mathrm{x}}, \mathrm{CO}, \mathrm{CO}_{2}$ emissions, real road emissions and reduces the time needed for dyno testing.

Jon Andersson (Ricardo, UK) presented the research program conducted for the CONCAWE association, concerning the possibility of reducing real road emissions by diesel-powered cars in terms of Euro 6d standards through the use of advanced SCR, SCRF and LNT catalytic systems in various configurations. The presented solutions show the possibility of fulfilling the limits of $\mathrm{PN}$ and $\mathrm{NO}_{\mathrm{x}}$ emissions by a car with a $\mathrm{CI}$ engine in various driving cycles, including those with high energy demand (WLTC, US06, RDE).

A properly selected SCR system ensures very low $\mathrm{NO}_{2}$ emissions from the vehicle, far below the limits and requirements for Euro 6d. He emphasised that Diesel engines
- recently much criticised for their environmental performance - should remain an important source of propulsion due to their high efficiency and existing catalytic solutions, allowing significant reduction of $\mathrm{NO}_{\mathrm{x}}$ emissions and the ability to meet emission limits also in RDE tests while maintaining their high efficiency and low $\mathrm{CO}_{2}$ emissions.

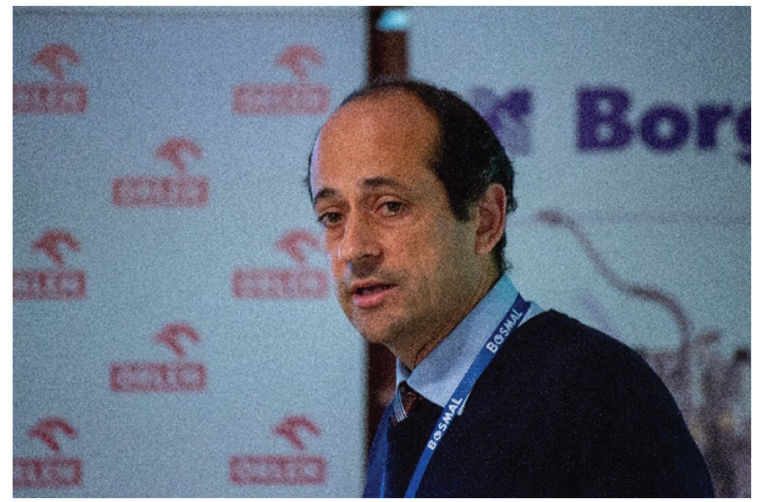

Fig. 8. Dr. Marcos Alonso Baez (Nissan Technical Centre Europe, Spain) delivering his presentation

Dr. Katarzyna Matusik (Argonne National Laboratory, USA; Fig. 9) presented advanced methods of testing fuel atomisation by injectors used in SI and CI engines using $\mathrm{X}$-ray and photon synchrotron diagnostics. This methodology allows for very accurate analysis of fuel atomisation through injector holes, stream shape, evaluation of cavitation problems, accurate hole geometry measurements and many quantitative other analyses of the atomisation of the fuel.

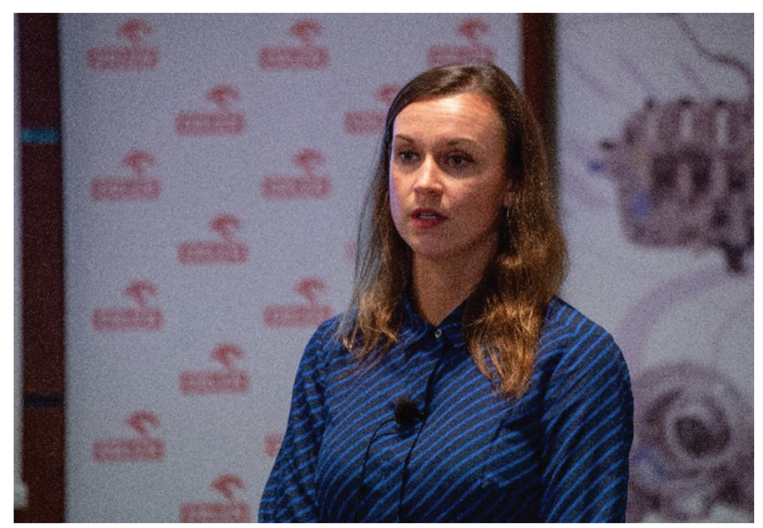

Fig. 9. Dr. Katarzyna Matusik (Argonne National Laboratory, USA) delivering her presentation

Dr. Tue Johannessen (Aminnex, Denmark) and Dr. Toni Kinnunen (Proventia, Finland) presented the possibilities of using advanced SCR catalytic systems to reduce $\mathrm{NO}_{\mathrm{x}}$ emissions in the captive fleet (i.e. currently used LD, HD vehicles and buses). This method is referred to as retrofitting and enables older vehicles to meet new emission standards at Euro 6 (LD) and Euro VI (HD) levels. This could significantly reduce the actual emissions from millions of vehicles with CI engines currently in use on Europe's roads. Examples of applications of this technique can be found in many cities in Germany and Scandinavia, as well as London buses. Maciej Hadryś (Mahle, Poland) presented new piston 
design solutions for SI and CI engines that allow their overall temperatures to be lowered and for better temperature distribution on the piston surface.

Paolo Patroncini (4-e Consulting, Italy) presented the development of "P-2 Architecture", modelling and design of hybrid powertrains for NRMM and off-road vehicles. For these types of vehicles and machines hybrid systems can be a promising solution. The first hybrid drive of this type is to be presented by the company 4-e Consulting and the University of Parma in November 2018.

The last two presentations in this session concerned particulates. The first covered methods for measuring the amount of soot in the DPF filter in CI engines using a special soot sensor developed by a team from the University in Thessaloniki, Greece, which can also be part of the OBD system. The reports as well as the problems with the accuracy of particle number measurements and calibration of devices used for this were presented by Prof. Savas Geivanidis the University in Thessaloniki.

The second presentation emphasised that PN measurement is one of the most difficult measurements in the field of automotive emissions testing. Work on this problem together with improving the accuracy of measurements and calibrations of measuring devices were presented by Alexander Terres (BMW/PTB, Germany; Fig. 10).

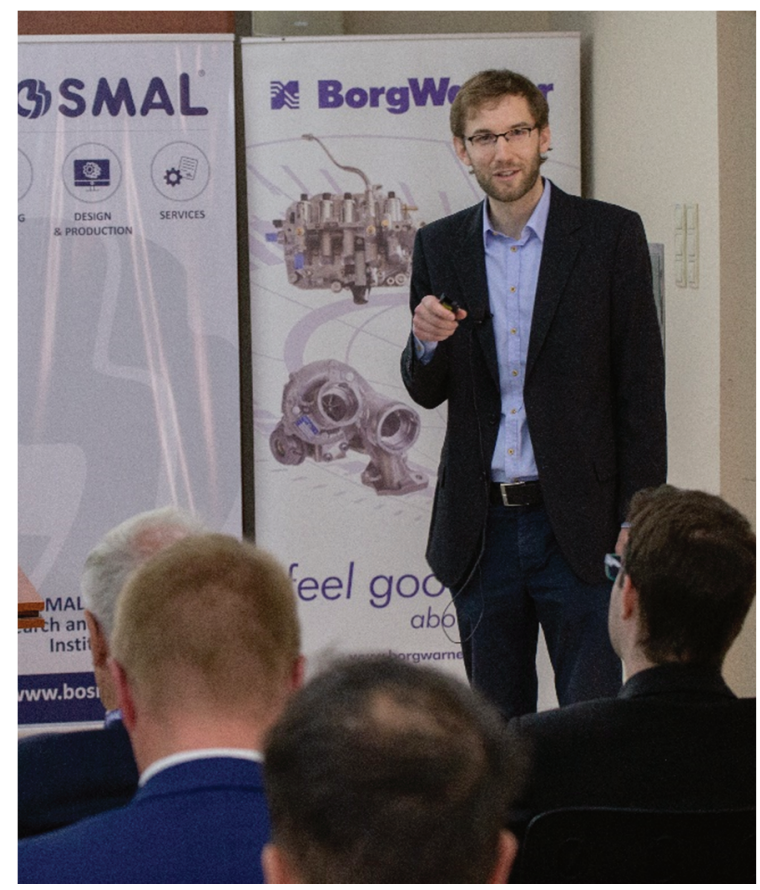

Fig. 10. Alexander Terres (BMW \& PTB, Germany) delivering his presentation

\subsubsection{Fourth Session}

The fourth session dealt with methods of automotive emissions testing, both in relation to laboratory tests and road tests using the RDE-PEMS method.

The new WLTP and RDE research methodologies were introduced in the provisions of Euro $6 \mathrm{c}$ and Euro 6d-TEMP and became applicable to new vehicle approvals from $1^{\text {st }}$ January 2017.
The first RDE package was published two years ago in the Commission Regulation (EU) 2016/427 and the second and third package in the Commission Regulations (EU) respectively 2016/626, 2017/1151 and 2017/1154 respectively. Further updates are expected late in 2018, as well as in future years.

Dr. Sophie Kinnear (Jaguar Land Rover, UK; Fig. 11) presented a report on advanced testing laboratories used for testing exhaust emissions on a chassis dynamometer, and on test benches for testing entire propulsion systems together with the methods for correlation of results between these two types of test stands. She used the examples of her company's laboratories in Whitley, Coventry in the UK.

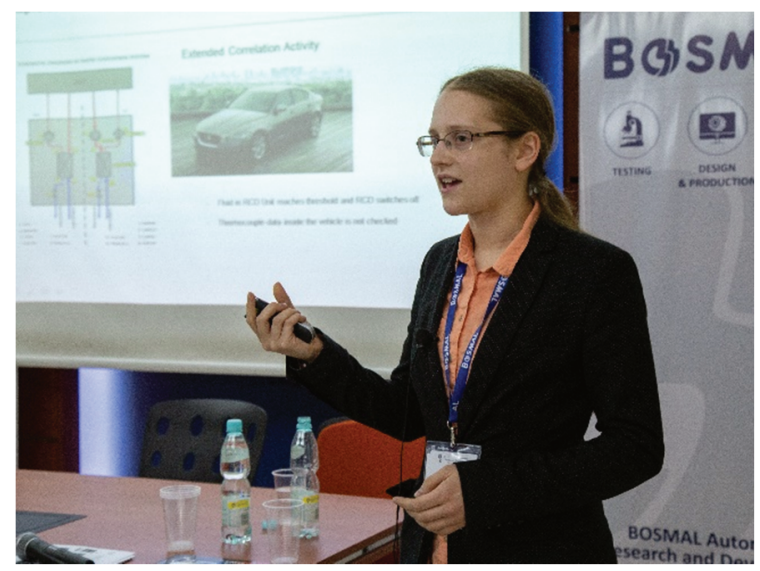

Fig. 11. Dr. Sophie Kinnear (Jaguar Land Rover, UK) delivering her presentation

Having extensive test bench capacity is now crucial to conduct development and adjustment of control systems for both internal combustion engines and associated systems (e.g. aftertreatment) in terms of meeting the requirements of the WLTP and RDE methodologies and new Euro 6d standards.

Sam van Goethem (TNO, the Netherlands) presented a new exhaust gas analyser for mobile measurements, referred to as SEMS (Smart Emissions Measurement System), based on sensors (as opposed to full chemical analysers), thermocouples and CAN bus connection via OBD II and J1939 interfaces. Such a system can measure fuel consumption, $\mathrm{CO}_{2}, \mathrm{NO}_{\mathrm{x}}$ and $\mathrm{NH}_{3}$ emissions and may also be useful in the continuous monitoring of these parameters in a vehicle.

In this session, a report on RDE research was also presented by Prof. Jerzy Merkisz (here representing Poznan University of Technology), who is a well-known expert on real-time emissions measurements performed under real operating conditions. He presented the results of investigations into many types of vehicles and machines powered by internal combustion engines, obtained using PEMS mobile analysers: passenger cars and trucks, buses, working machines and off-road vehicles and even trains, ships and aircraft. He also presented revealing comparisons of actual exhaust emissions from various types of vehicles and working machines.

Professor Gordon Andrews (University of Leeds, UK; Fig. 12) emphasised the fact that the largest local air pollu- 
tion levels are caused by traffic jams and sub-optimal or inadequate road layout, which is related to the low mean driving speed, the high frequency of stop events and the frequency and intensity of acceleration events, which often occur from idling. This is the main cause of high levels of air pollution in urban areas. Traffic conditions with very high emissions intensity and very low mean speed (below $15 \mathrm{~km} / \mathrm{h}$ ) are not included in the new WLTP and RDE tests. RDE tests of cars and heavy goods vehicles with an SCR catalytic system on congested roads in Leeds, UK as well as in China have shown that the highest emissions occurred when pulling away from a standstill and that the final emissions are correlated with the mean driving speed, a revelation which should be taken into account in further modifications to RDE regulations.

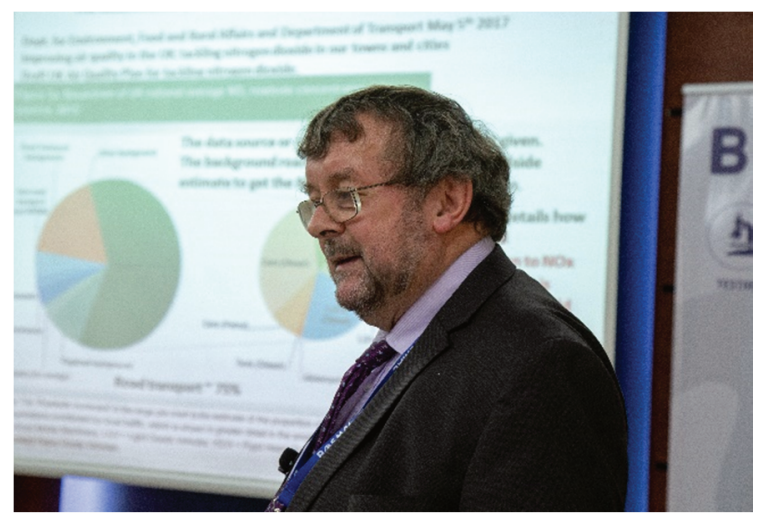

Fig. 12. Prof. Gordon Andrews ( University of Leeds, UK) delivering his presentation

\subsubsection{Fifth Session}

The fifth and final session concerned the development of motor fuels and alternative powertrains (here mainly electric vehicles).

Dr. Johannes Villinger (V\&F, Austria) presented the possibility of using oxymethylether (OME) as a fuel for the possibility of improving the properties of alternative fuels and biofuels. He also presented the need for further work on the development of alternative fuels, despite the currently low prices of mineral fuels (those derived from crude oil/natural gas) and the possibility of improving the combustion process within the engine using additives for properly composed fuels. He presented the research possibilities of various advanced measuring instruments for exhaust gas composition analysis based on mass spectrometers for analysis of raw exhaust gas.

Another two consecutive reports were devoted to electric cars. This subject was discussed for the first time during the Exhaust Emissions Symposia at BOSMAL, however, it was justified by the increasing political pressure on the introduction of fully electric vehicles, and on the other hand the desire to thoroughly assess such propulsion systems both in terms of their ecological performance (so-called "source to wheel" analysis), as well as the advantages and disadvantages of this type of energy storage \& propulsion system compared to conventional internal combustion engines (including hybrids) and liquid hydrocarbon fuels.
Dr. Piotr Bielaczyc (co-author Dr. Marek Ryłko a well-known expert on hybrids and electric vehicles) presented a general report on the history, characteristics as well as the advantages and disadvantages of electric vehicle drives.

The first electric vehicles were built as early as 1830 , much earlier than vehicles powered by internal combustion engines. Around the year 1910, electric vehicles were dominant on the passenger car market, but the introduction of an electric starter, which replaced the crank in cars with internal combustion engines, and on the other hand, the much higher price of electric cars caused a significant drop in interest in these cars. We are now observing a renaissance in interest for electric powertrains and vehicles, which can be a good solution, especially in crowded cities and heavily urbanised areas.

However, there are many barriers and disadvantages of these vehicles and one of the most important of these is the low energy density that can be stored in a lithium-ion battery, which is equivalent to only about $4 \%$ of the energy contained in liquid fuels. This means that the amount of energy that can be stored, for example, in a $125 \mathrm{~kg}$ battery corresponds to the same amount of energy contained in 4.5 litres of gasoline (i.e. $\sim 10 \%$ of the capacity of a typical passenger car's fuel tank).

Another problem is the infrastructure for charging electric car batteries. In the final presentation, Dr. Marek Sutkowski (Horus Energia, Poland) presented some insights into this subject. He explained that each car needs about 40 $\mathrm{kWh}$ of electricity to fully charge the battery, which corresponds to $8 \mathrm{~h}$ of charging at $5 \mathrm{~kW}$, or $30-40$ minutes with a charging capacity of $100-150 \mathrm{~kW}$ (although in practice much more power - some $350 \mathrm{~kW}$ - would be recommended); such high power levels require special battery charging infrastructure, thus necessitating the construction of additional power plants and transmission lines in addition to the final charging points. A possible solution to this problem, according to the author, would be to build a network of charging stations based on generators equipped with large combustion engines that would be powered by Diesel or CNG. This, however, only confirms the thesis that the combustion engine is more universal than the electric motor, because it can convert the energy contained in the fuel into work by itself, without the need for large, heavy and costly energy storage systems.

\section{Conclusions}

During the 6th Symposium on Exhaust Emissions, all issues relating to the emission of harmful exhaust gases, greenhouse gases from automotive sources and the directions in which the development of vehicle's drive based on both internal combustion engines, hybrid drives and electric motors are going were discussed.

Conclusions and observations regarding the current (Euro $6 \mathrm{c}$, Euro 6d-TEMP, and Euro 6d in the European Union) and the future (planned post-Euro 6 and Euro 7) legal status limiting the emission of harmful and toxic exhaust components were presented.

Conclusions regarding the reduction of fuel consumption and emission of carbon dioxide $\left(\mathrm{CO}_{2}\right)$, methods of reducing these emissions, development of test methodology for ex- 
haust emissions from internal combustion engines used in motor vehicles and other means of transport as well as offroad vehicles and working machines were also discussed.

Reducing emissions of harmful compounds and toxic fumes, and now the especially important reduction of particulate matter $(\mathrm{PM})$ in terms of their mass and number (PN) of emitted nanoparticles, reduction of real $\mathrm{NO}_{\mathrm{x}}$ emissions, as well as new tests and WLTP and RDE emission testing methodology are the main challenges for the automotive and motor industries caused by political, economic and technical factors.

The new WLTP and RDE research methods, which are a milestone in the development of vehicle tests which also require new engine designs and exhaust after treatment systems, are also the focus of certification authorities in other countries, notably Japan, China, India and South Korea. These countries plan to introduce them in the coming years. These works are also closely watched and partly supported by countries such as the USA and Canada.

New challenges currently faced by manufacturers of drive systems of motor vehicles, but also off-road vehicles and working machines, related to the decarbonisation of the economy, the need to reduce fuel consumption, which is equivalent to reducing greenhouse gas (GHG) emissions, especially $\mathrm{CO}_{2}$, caused the necessity of further development of various types of powertrains: both internal combustion engines, adapted to be fuelled with improved fuels of mineral origin, as well as new types of ecological and alternative fuels, hybrid systems, built from an internal combustion engine and an electric motor, especially in the Plug-in Hybrid system, as well as fully electric powertrains.

Currently, the development and introduction of innovative electronic solutions has made electric motors better, quieter and much more powerful and can be an independent or combined (hybrid) source of vehicle propulsion, which will be of great importance especially for vehicles used in city centres and heavily urbanised areas.
In the current era of increasingly stringent emission standards for the automotive industry, electric motors are again becoming a major main focus of attention, constituting an important development focus for the entire automotive industry.

In addition to continuous improvements in electric motor technology, making electric and hybrid vehicles more competitive compared to conventional internal combustion engines (ICEs) in many markets, lawmakers and research and development organisations are constantly working on test methods and test equipment for these types of vehicles and powertrains.

According to experts, despite the growing popularity of electric vehicles, over $90 \%$ of new vehicles will still be powered by an internal combustion engine in 2025 .

Internal combustion engines - including Diesel engines will continue to be the main source of power for motor vehicles and working machines for many years, due to their high efficiency, the ability to produce very clean engines, the availability of liquid and gas fuels, as well as the development of renewable fuel technologies and even synthetic fuels.

These motors will also be combined with electric motors as a hybrid unit in the future, which will have a great impact, especially on the specific applications of vehicles and working machines.

It is important to develop production technologies for low-carbon alternative fuels and biofuels, as well as electricity from renewable sources.

Compliance to the emission limits in the new WLTC cycles and measurements in real RDE traffic, as well as the introduction of new research methods for the study of hybrid and electric powertrains is a very complicated and expensive process for vehicle manufacturers, requiring increased investment in research and development and even entire new research laboratories, which is what BOSMAL has been doing for years, making it currently the largest research and development facility of its type in Central and Eastern Europe (Fig. 13).

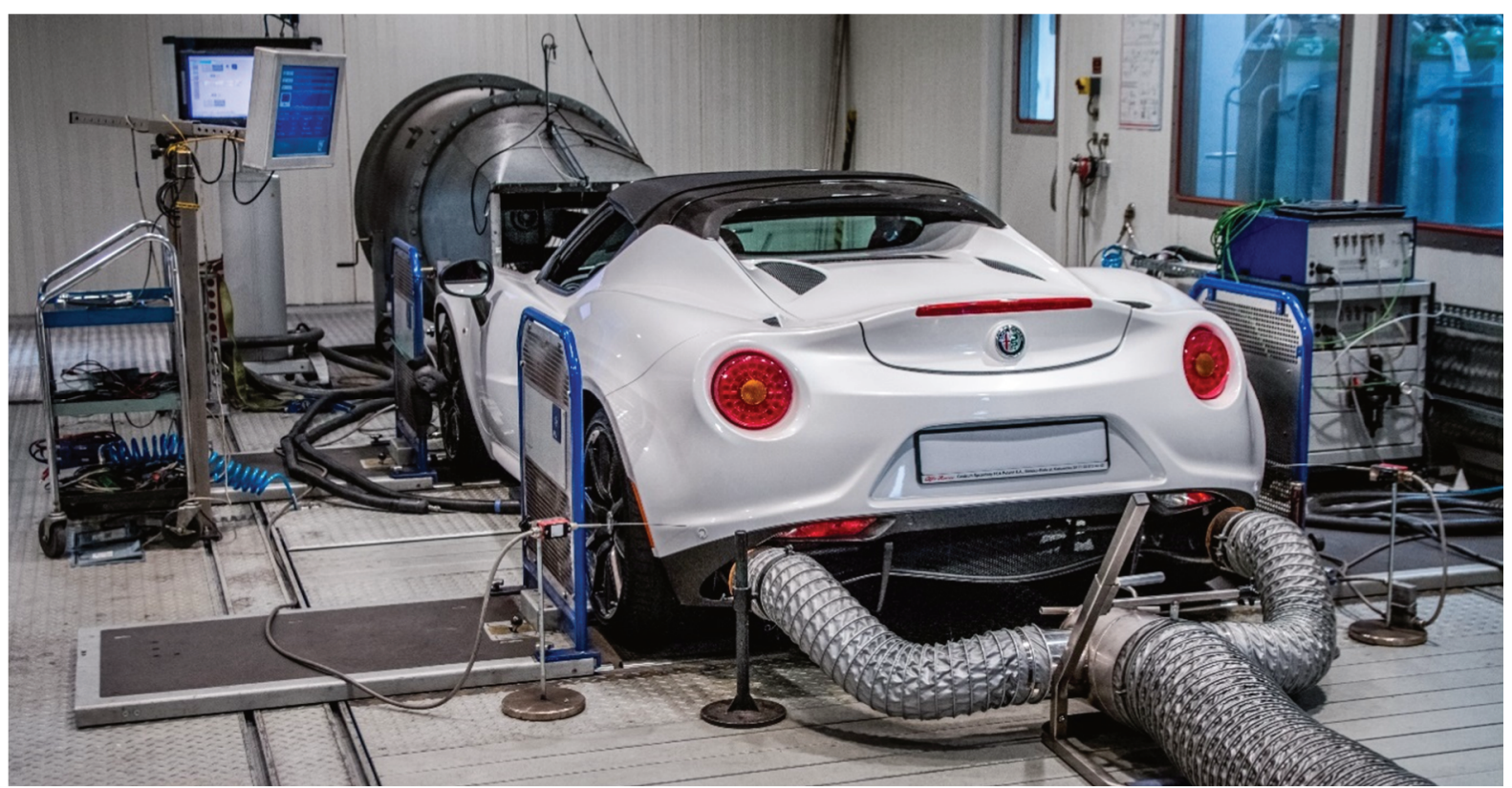

Fig. 13. BOSMAL's climate-controlled 4WD chassis dynamometer for R\&D and certification work on conventional, hybrid and fully electric powertrains 
The process of testing and quantifying the efficiency of hybrid drives and electric motors in the automotive industry is based on conducting research on special test stands for development and calibration of drive systems based on the use of test cells similar to those for testing internal combustion engines equipped with dynamometers based on $\mathrm{AC}$ asynchronous motors. However, due to the growing popularity of electric motors in the automotive industry (hybrid and electrical solutions) it is undoubtedly necessary to develop an appropriate, systematic and coherent research methodology for researching and testing such engines. An instance of this is work on the research methodology for vehicles with electric, hybrid (Diesel-electric) and hydrogen fuel cells.

Experts participating in the symposium anticipated that in the coming years, intensive research and development will be carried out for the following types of vehicle drives, which will be produced in 2020-2025 and in later years:

a) new types in internal combustion engines developed according to the "rightsizing" concept in LD and HD versions, which will aim to meet Euro 6d, post-Euro 6/Euro VI - Euro 7/Euro VII standards, also adapted to the new generation of motor fuels and alternative fuels (with the addition of HVO, ethanol/methanol, low carbon fuels, CNG, hydrogen and perhaps even other types), with mild hybrid systems or other hybrid systems used in the future

b) a new generation of exhaust gas aftertreatment systems, especially SCR systems for CI engines and GPF filters for direct injection fuel injection engines (with highly refined and accurate Ad-blue dosing, filter regeneration, etc.),

c) SI and CI engines developed for cooperation with electric motors in hybrid systems, especially Plug-in-hybrid, for various applications,

d) hybrid powertrains for vehicles consisting of SI or CI engines and electric motors in various configurations and with different control systems, e) electric motors of various types used for powertrains of $\mathrm{LD}$ and $\mathrm{HD}$ vehicles with a maximum engine power of up to approximately $250 \mathrm{~kW}$.

These types of powertrains will have to meet the new requirements which are included among others within UNECE regulations and European Union regulations, such as: GTR15 Regulations, with proposals for amendments to GTR15 (Proposal for Amendment 4 and 5 to Global Technical Regulation No. 15 (Worldwide Harmonised Light Vehicle Test Procedure (WLTP)), United Nations ECE/ Trans/WP.29/GRPE/2018/1), newly developed by the GRPE (UN) group, GTR RDE Regulations, new research methods in the preparation of, among others, IWG group Electric Vehicles and Environment.

The presentations, abstracts and posters submitted to the 6th IEES are included in conference materials entitled: "Symposium Proceedings - Trends in Automotive emissions legislation: Impact on LD engine development, fuels lubricants and test methods - a global view with focus on the WLTP and RDE regulations", ISBN 978-83-946334-17, issued by BOSMAL on CD [6]; a printed Book of Abstracts is also available, ISBN 978- 83-946334-2-4 [7].

A film documenting and reporting on the symposium is archived on a DVD that will be attached to the Combustion Engines number 3/2018. A special edition of the journal Combustion Engines (3/2018) will also be released with articles and presentations from the symposium. Diesel Net (Canada) has prepared a report on the symposium, which is freely available online [8]. The summary of the symposium will also be included in the scientific journal Emission Control Science \& Technology, an international journal published by Springer in New York, USA. Information and reports from previous iterations of the IEES (2010-2016) are available in previous issues of Combustion Engines, as well as in various volumes issued by BOSMAL and on the internet [9-25].

\section{Bibliography}

[1] DILARA, P. The development of Real Driving Emissions Test. 2nd Sino-EU Workshop on New Emissions Standards for Motor Vehicles. June 19th-20th, 2018, Brussels, Belgium.

[2] NEUGEBAUER, S. Technological scenarios for the decarbonization of road transport. Proceedings "Connectivity key to future emission and consumption reduction? In Vehicle and Powertrain" 30th International AVL Conference "Engine \& Environment", 7th-8th June 2018, Graz, Austria.

[3] KOBAYASHI, T. Outline and issues of RDE test in Japan. 2nd Sino-EU Workshop on New Emissions Standards for Motor Vehicles. June 19th-20th, 2018, Brussels, Belgium.

[4] Proposal for Amendment 4 to Global Technical Regulation No. 15 (Worldwide harmonized Light vehicles Test Procedure (WLTP)), United Nations ECE/Trans/WP.29/GRPE/ 2018/1.

[5] BIELACZYC, P., WOODBURN, J., GANDYK, M. Trends in automotive emissions, fuels, lubricants, legislation and test methods - a global view, with a focus on the EU and US - Summary of the 5th International Exhaust Emissions
Symposium (IEES). Combustion Engines. 2016, 166(3), 7882, DOI: $10.19206 /$ CE-2016-342.

[6] BIELACZYC, P., WOODBURN, J. (editors) "Symposium Proceedings - Trends in automotive emissions legislation: impact on LD engine development, fuels lubricants and test methods - a global view with focus on the WLTP and RDE regulations", ISBN 978-83-946334-1-7, BOSMAL, BielskoBiala 2018.

[7] BIELACZYC, P., WOODBURN, J. (editors) Book of Abstracts of the 6th International Exhaust Emissions Symposium, ISBN 978-83-946334-2-4, BOSMAL, Bielsko-Biala 2018.

[8] https://dieselnet.com/news/2018/06bosmal.php

[9] BIELACZYC, P., WOODBURN, J. Global trends in emissions regulation and reduction. Combustion Engines. 2010, 142(3), 3-27, 2010.

[10] BIELACZYC, P. (editor) and 13 co-authors. Global trends in emissions regulation and reduction from the perspective of powertrain and fuel development. Proceedings of the 1st International Exhaust Emissions Symposium, ISBN 978-83931383-0-2, 2010. 
[11] BIELACZYC, P., WOODBURN, J. Analysis of current and future trends in automotive emissions, fuels, lubricants and test methods. Combustion Engines. 2011, 147(4), 104-118, 2011.

[12] BIELACZYC, P. (editor) and 17 co-authors. Global trends in emissions regulation and reduction from the perspective of powertrain and fuel development. Proceedings of the 2 nd International Exhaust Emissions Symposium. ISBN 978-83931383-1-9, 2011.

[13] BIELACZYC, P., WOODBURN, J. Current and future trends in automotive emissions, fuels, lubricants and test methods - the view from the year 2012. Combustion Engines. 2012, 149(2), 94-116, 2012.

[14] BIELACZYC, P. (editor) and 21 co-authors. Current and future trends in automotive emissions, fuels, lubricants and test methods - 2012. Proceedings of the 3rd International Exhaust Emissions Symposium. ISBN 978-83-931383-2-6, 2012.

[15] BIELACZYC, P., CZERWINSKI, J., WOODBURN, J. Current trends in measurement and control of particle emissions from engines. Combustion Engines. 2012, 150(3), 8996, 2012.

[16] BIELACZYC, P. (editor) and 18 co-authors. Particulate matter emissions from engine and automobile sources. Proceedings of the 1st Workshop on Particulate Matter Emissions from Engine and Automobile Sources. ISBN 978-83931-383-3-3, 2012.

[17] BIELACZYC, P., SUTKOWSKI, M. (editors) and 5 coauthors. Gaseous fuels in power generation and the automotive sector. Proceedings of the technical seminar on gaseous fuels in power generation and the automotive sector. ISBN 978-83-931383-4-0, 2012.

[18] BIELACZYC, P., WOODBURN, J. Powertrain development for low-to-zero emissions and efficient energy usage -

Piotr Bielaczyc, DEng. - BOSMAL Automotive Research and Development Institute Ltd in BielskoBiała, Poland.

e-mail: Piotr.Bielaczyc@bosmal.com.pl

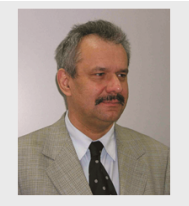

the industry session held during the 5th PTNSS congress on combustion engines. Combustion Engines. 2013, 155(4), 7579, 2013.

[19] BIELACZYC, P. (editor) and 19 co-authors. Powertrain development for low-to-zero emissions and efficient energy usage. Proceedings of the Industry Session held during the 2013 PTNSS Congress on Combustion Engines. ISBN 97883-931-383-5-7, 2013.

[20] BIELACZYC, P. (editor) Trends in automotive emissions, fuels, lubricants, legislation and test methods present and future - 2014. Symposium Proceedings of 4th International Exhaust Emissions Symposium , 22-23 May 2014, BielskoBiala, Poland, ISBN 978-83-931383-7-1. Published also in Combustion Engines. 2014, 158(3), ISSN 0138-0346.

[21] BIELACZYC, P., WOODBURN, J. Trends in automotive emissions, fuels, lubricants, legislation and test methods present and future. A brief overview from the perspective of the International Organising Committee of the 4th International Emissions Symposium. Combustion Engines. 2014, 158(3), 93-100, ISSN 0138-0346.

[22] https://www.dieselnet.com/news/2014/05bosmal.php

[23] BIELACZYC, P., WOODBURN, J., GANDYK, M. Trends in automotive emissions, fuels, lubricants, legislation and test methods - a global view, with a focus on the EU \& US. Combustion Engines. 2016, 166(3), 76-82. DOI:10.19206/ CE-2016-342.

[24] BIELACZYC, P. (editor), Symposium Proceedings - Trends in automotive emissions, fuels, lubricants and test methods a global view with focus on the EU \& US. Proceedings of the 5th International Exhaust Emissions Symposium. 19-20 May 2016, Bielsko-Biala, Poland, ISBN 978-83-931383-9-5.

[25] https://www.dieselnet.com/news/2016/05bosmal.php

Joseph Woodburn, MSci - BOSMAL Automotive Research and Development Institute Ltd in BielskoBiała, Poland.

e-mail: Joseph.Woodburn@bosmal.com.pl

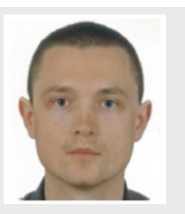

